\title{
Physico-chemical Study of Surface Seawater in The Northwestern Gulf of Suez
}

\author{
M.M. Emara, N.A. Farid", E. A. El-Sabagh ${ }^{* *}$, O.E. Ahmed ${ }^{* * \#}$ \\ and E.M. Kamal ${ }^{*: n}$ \\ Chemistry Department, Faculty of Science (Boys), Al-Azhar \\ University, ${ }^{*}$ Egyptian Petroleum Research Institute and ${ }^{* *}$ Chemistry \\ Department, Faculty of Science (Girls), Al-Azhar University, \\ Cairo, Egypt.
}

\begin{abstract}
UEZ Canal is a narrow artificial water way in Egypt that joins the Mediterranean Sea with the Red Sea. The Suez Canal passes through an area with a considerable agricultual and industrial activities, so that the chemical and petrochemical pollution from oil transporting process can be effective. Eight surface seawater samples were collected from different sites extended from Suez Harbor up to Fertilizer factory, and both of Al-Osra and Al-Melaha beaches along Suez Gulf. The objective of this study is the monitoring and assessing the contamination of water by chemical and petrochemical pollutions. This study includes physical and chemical parameters of water such as PH values, conductivity, salinity, T.D.S, T.S.S, T.S, D.O., BOD, $\mathrm{COD}, \mathrm{Cl}^{-}, \mathrm{SO}_{4}^{-}, \mathrm{NO}_{3}^{-}$and total alkalinity. Seasonal qualitative and quantitative studies have been carried out on the studied area. The concentration is relatively higher than recommended in the regulations of the Egyptian low environment No.4/1994. Results obtained from the present study should be considered when implementing a strategy for the protection and management of the Suez Gulf. Because the Suez Gulf is used in many areas as a recipient of waste water from different sources this study recommended that pollution control for wastewater disposing into it should be improved. More detailed studies are required to assess the impact of hydro- development projects and evaluate their effect on the studied area and monitoring should be conducted at least twice per year.
\end{abstract}

Keywords: Physico-chemical properties, Seawater analysis, Suez Gulf, Nutrient salts, Total alkalinity and Ion concentration.

The Suez Canal is located in the northeast of Egypt .Thee geographical position of the Suez Canal makes it the shortest route between east and west that leads to increase the passage of many tender convoys and ships through it (Fig. 1). It extends from Port Tewfik in South with overall length $162 \mathrm{kms}$ and $22.5 \mathrm{~m}$ water depth, the Suez canal passes through an area of considerable agricultural, industrial and tourist activity. So the relation between human activities and environmental changes in Suez Canal require knowledge of trends in water quality and understanding of the management of aquatic habitats. The significance of observed contamination level must be measured and special

\footnotetext{
\#Corresponding author: dr.omaymamosa@yahoo.com
} 
attention to a number of substance like synthetic biocides' radioactive materials, heavy metals and oil residues ${ }^{(1)}$ must be paid. These substances can be sensitive for monitoring contaminants in aquatic environments. Therefore it is easy to dispose waste by dumping it into a river or lake and canals. In large or small amounts, dumped intentionally or accidentally, it may be carried away by the current, but will never disappear. It will reappear downstream, sometimes in changed form, or just diluted. Freshwater bodies have a great ability to break down some waste materials. This overload that results, called pollution, eventually puts the ecosystem out of balance. Sometimes nature itself can produce these imbalances. Most often our waterways are being polluted by municipal, agricultural and industrial wastes, including many toxic synthetic chemicals, which cannot be broken down at all by natural processes. Even in tiny amounts, some of these substances can cause a serious problem. Also, chemical pollution is an other source from factories and agricultural drainage which may be discharged into the canal, Chemicals can cause health problem to seafood present in seawater and their concentration can be increased by man's activities $^{(2)}$. Water samples were collected from the Gulf of Suez during July, 1998. Nutrient salts (ammonia, nitrite, nitrate and phosphate) were measured spectrofluorometrically. The results show that nutrient salts were relatively high at the northern part of the Gulf of Suez (Suez Bay). Their concentrations were 4.14, 0.45, 4.6 and $1.04 \mathrm{ng}$ at/L for $\mathrm{NH} /, \mathrm{NO}_{2}{ }^{\prime \prime}, \mathrm{NO}_{3}$ " and $\mathrm{PO}_{4} "$, respectively. The present study revealed that the Suez Bay area can be considered as eutrophic region. This is related to sewage and/or industrial waste discharges along the western coast of the bay. The rest of the Gulf area is considered as Oligotrophic region. Also, the results show that nitrogen is the limiting factor for phytoplankton growth in the Gulf of Suez ${ }^{(3)}$. The wastewater of the Suez Gulf: As the Suez Canal becomes the passage to the international trade between east and west, several wastes are easily disposed and dumping into the boundaries of the studied area .The pollutants vary from raw sewage, oil spills, and industrial effluents to garbage which has tremendous impacts on the marine environment. The marine environment of the bays in Suez Gulf is subjected to mixed sources of pollution (industrial, agricultural and domestic sewage) through the direct discharge of El-Kabanon drain, which is considered as the main industrial and sanitary drain. Sewage of approximately 120,000 m3 /day is dumped through ElKabanon drain into the bay in Suez Gulf. The sewage discharged contains 94 ton/year of ammonia, 0.31 ton/year of nitrite, 0.40 ton/year of nitrate, 53 ton/year of inorganic phosphate, 0.41 ton/year of copper, 3.7 ton/year of zinc and 0.12 ton/year of lead. Research was carried out on heavy metal pollution in the region, where the bay is subjected to industrial run-off from oil refineries, fertilizer plants, and power station in addition to sewage and garbage. The heavy metal concentrations ranged from 7.2 to $148 \mu \mathrm{g} / \mathrm{l}$ for $\mathrm{Zn}, 10$ to $63 \mu \mathrm{g} / \mathrm{l}$ for $\mathrm{Cu}, 0.7$ to 12 $\mu \mathrm{g} / \mathrm{l}$ for $\mathrm{Pb}$ and 0.01 to $1.3 \mu \mathrm{g} / 1$ for $\mathrm{Cd}$, respectively. Adabiya station showed the highest values, because of the various pollution sources discharged (i.e., harbors, sewage, and industrial drains), while in contrast the station of Moon Beach showed the lowest concentrations. The Moon Beach area in the Suez Gulf was also found to suffer from extensive chronic petroleum pollution inputs, as it is evident in the vicinity of the SUMED pipeline company terminals, which include

Egypt. J. Chem. 56, No. 5,6 (2013) 
both floating and land-based receiving terminals ${ }^{(4)}$. Most of these pollutants occurred from the human activities. The Suez bay area is subjected to pollution from three main sources: (1) Industrial waste: which come from different factories such as petroleum companies (Misr Petroleum Company, Suez Petroleum Company and Al- Nasr Petroleum Company for refining the crude oil). Suez Oil Company produce the final products of fuel gases , propane , butane, gasoline ,jet fuel , kerosene, gas oil, asphalt and coke, sulphur and lube oil . The amount of discharged waste water from Suez oil company to Suez bay is 360000-m3/day industrial water only. The concentration of heavy metals ( $\mathrm{pb}$, $\mathrm{Cu}, \mathrm{Zn}, \& \mathrm{Fe}$ ) from the companies effluent during the year 2003 and 2004 reached to $520,69.5,41.7$ and $1186.2 \mathrm{mg} / \mathrm{l}$, respectively ${ }^{(5)}$. (2) Domestic draining of the Suez City: may contain sludge arising from the treatment of sewage. Municipal sewage sludge may have harmful effects such as oxygen depletion and eutrophication, while health risks may arise from the presence of pathogens if dump sites are not carefully selected. (3) Ship's oil: The waste from repairing ships in Port Tewfik also marine transportation; including tanker operations, other shipping activities and accidental spills from ships represents another input of oil to Suez Canal ${ }^{(6)}$.

\section{Materials and Methods}

Area of study on Suez Gulf

Suez bay is the entrance of (Gulf sea) Red sea and is limited by latitudes $29^{\circ} 54^{\circ}$ and $29^{\circ} 57^{\circ} \mathrm{N}$, and longitudes $32^{\circ} 28^{\circ}$ and $32^{\circ} 34^{\circ} \mathrm{E}$, (Fig. 1). It is an important shipping route for oil tankers and other ships traveling through the Suez Canal ${ }^{(7)}$.

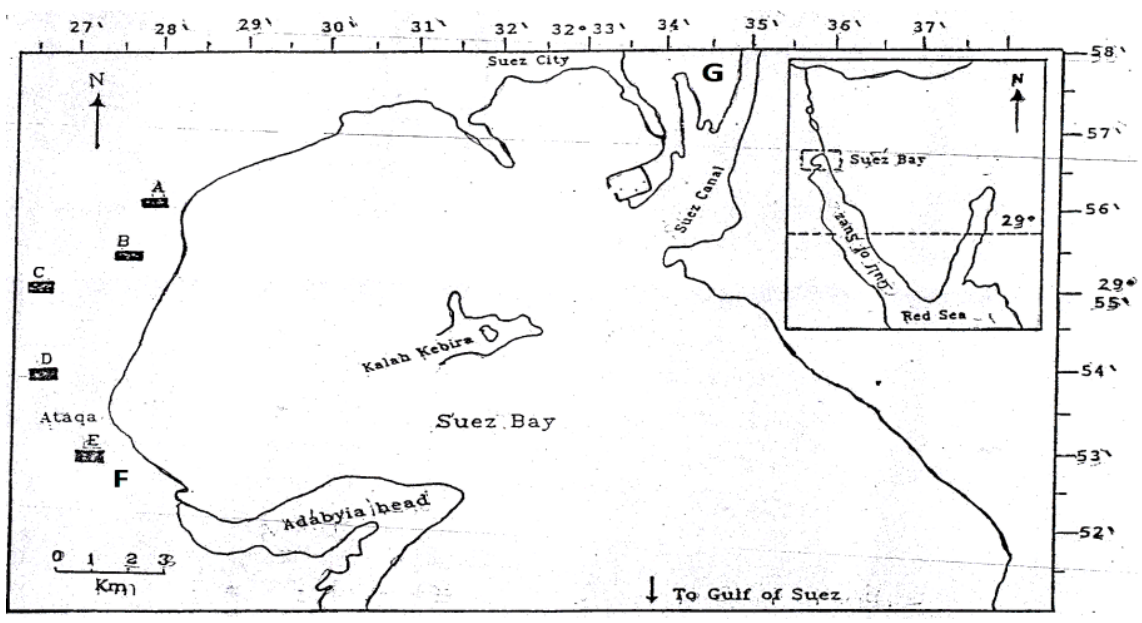

Fig. 1. Map of Suez Bay showing position of the sources of pollution. A: Al-Nasr Oil Company, B\& C: inlet and outlet of Suez Oil Company \& D: Electricity Station \& E: Fertilizer Factory \& F: AL-Osra \&Al-Melaha beaches. 
Samples collection and storage.

Surface water $(0-2 \mathrm{~cm})$ samples were collected from Suez Gulf, the studied areas including industrial zones and beaches (Table 1). It extended from Suez Harbor up to Fertilizer factory, and both of Al-Osra, AlMelaha beaches a long Suez Gulf with a maximum distances nearly $21 \mathrm{~km}$ along Suez Gulf. Eight surface water samples with one liter for each other were taken from on-shore sites using precleaned glass bottles to minimize contamination with components of ambient air during storage of sampling and then the bottles were refrigerated for analysis ${ }^{(8)}$.

TABLE 1. Studied sites, their location and distance from Suez Harbor.

\begin{tabular}{|c|c|c|}
\hline Site No. & Location & $\begin{array}{c}\text { Distance from } \\
\text { Suez Harb. }(\mathbf{K m})\end{array}$ \\
\hline 1 & Suez Harbor. & $2(\mathrm{Km})$ \\
\hline 2 & Al-Nasr Oil Company & $5(\mathrm{Km})$ \\
\hline 3 & Inlet of Suez Oil Company & $7(\mathrm{Km})$ \\
\hline 4 & Outlet of Suez Oil Company. & $9(\mathrm{Km})$ \\
\hline 5 & Outlet of Electrical Station Company. & $10(\mathrm{Km})$ \\
\hline 6 & Fertilizer Factory & $18(\mathrm{Km})$ \\
\hline 7 & Al-Osra beach & $20(\mathrm{Km})$ \\
\hline 8 & Al-Melaha beach & $21(\mathrm{Km})$ \\
\hline
\end{tabular}

Harb.: Harbour Harb: Harbor.

\section{General physico - chemical properties}

The objective of this study is the monitoring and assessing the contamination of water by chemical and petrochemical pollutions. This study includes physical and chemical parameters of water such as $\mathrm{PH}$ values, electrical conductivity, salinity, T.D.S,T.S.S,T.S,D.O.,BOD,COD, $\mathrm{Cl}^{-}, \mathrm{SO}_{4}{ }^{-}, \mathrm{NO}_{3}^{-}{ }_{3} \mathrm{PO}_{4}^{-}$and total alkalinity were determined for the seawater under study. All analyses had been achieved according to the following standard methods:

1. PH: The $\mathrm{pH}$ was determined using the electrometric method according to the ASTM D1293 ${ }^{(9)}$ and APHA $4500 \mathrm{H},{ }^{+(10)}$. The $\mathrm{pH}$ was measured at $25{ }^{\circ} \mathrm{C}$ using a digital $\mathrm{pH}$ - meter, Hanna model $\mathrm{pH} 213$, equipped with a combination $\mathrm{pH}$ electrode, HI $1230 \mathrm{~B}$.

2. Biochemical and chemical oxygen demands for seawater were determined according to standard method described in details ${ }^{(11)}$.

3. Electrical conductivity: The electrical conductivity was determined using the instrumental method according to the ASTM D1125 ${ }^{(9)}$ and APHA 2510, ${ }^{+(10)}$. The conductivity of the seawater was determined at $25^{\circ} \mathrm{C}$ using a digital conductivity meter, WTW, model Cond 3301, equipped with a conductivity cell. The resistivity of the water samples was calculated from their obtained conductivity values.

4. Dissolved solids: Total dissolved solids were determined according to the ASTM D1888 ${ }^{(9)}$ and APHA $2540^{(10)}$, methods at $105^{\circ} \mathrm{C}$ by drying suitable aliquots of the water samples at $105^{\circ} \mathrm{C}$ in an oven.

Egypt. J. Chem. 56, No. 5,6 (2013) 
5. Salinity: The salinity of the water samples were estimated from the determined chloride concentration to give the salinity as sodium chloride.

6. Alkalinity: The bicarbonate alkalinity was determined by the titration method according to the ASTM D1067 and D3875, ${ }^{(9)}$ and APHA $2320^{(10)}$. A suitable aliquot of the water sample was titrated to the $\mathrm{pH} 4.5$, with a standard hydrochloric acid solution, calculations was done using Alkalinity Calculator Ver. 2.10. The alkalinity, as calcium carbonate, was calculated.

7. Determination of anions: Anions including fluoride, chloride, nitrate and sulfate were determined by the ion chromatography according to the ASTM D4327 ${ }^{(9)}$ and APHA 4110, ${ }^{(10)}$, using ion chromatography DX 600 gradient IC system (Dionex, Sunnyvale, CA, USA). The separated components were detected by auto suppressed conductivity using E D50 Electro - chemical detector in the conductivity mode. An electrochemical self regenerated suppressor ASRS Ultra II 4-mm was used for suppression. Meanwhile, Ion Pac AS9-HC (4 x $250 \mathrm{~mm}$ ). Separation column with Ion Pac AG9 (50 X 4 mm) guard column was used for separation by 9.0 mmol $\mathrm{Na}_{2} \mathrm{CO}_{3}$ solution at a flow rate of $1 \mathrm{ml} / \mathrm{min}$. Integration was performed by Chrome-leon Ver. 6.30 software (Dionex).

\section{Results and Discussion}

Samples have been chosen for this study according to the location and activities taking place in each site. The main activities which may cause pollution are loading and unloading of ships in harbors, industrial and agricultural activities in addition to petroleum chemical and petrochemical wastes. Eight locations were chosen for this study starting from Suez Harbor site No. (1), to Al-Melaha beach site No. (8) (Table 1).

$\mathrm{PH}$ values ranged from 7.23 up to 8.20 in summer and 7.33 to 8.30 in winter with average values 7.62 and 7.65, respectively (Table 2 and Fig. 2) . Normal pH value in seawater is between 8.0-8.2 at the surface, decreasing to 7.7-7.8 with increasing depths ${ }^{(12)}$. In the Gulf of Suez, $\mathrm{pH}$ values were found to increase southwards, where the maximum $\mathrm{pH}$ of $8.20 \& 8.30$ was recorded at Inlet and outlet of Suez Oil Company for summer and winter, respectively while, a minimum $\mathrm{pH}$ of was recorded at Al-Osra beach and Suez Harbor for summer and winter, respectively which is affected by the disposal of mainly acidic sewage and industrial effluents, in addition to oil refineries effluents distributed in the Suez Bay. In general PH of Suez Gulf is slightly alkaline varing from region to another depending upon the location of sampling and independent on the season.

Electrical conductivity (EC): The Conductivity of an electrolytic solution depends on the ions present and their concentrations. The conductivity readings reflect the level of total dissolved solids (T.D.S) in wastewater (13, ${ }^{4)}$. Data showed that the conductivity values in the summer are greater than those recorded in the winter (Table 2 and Fig. 3). This may be related to mixing of salty water from the Suez Gulf with oil during the process of withdrawing petroleum considered as a source of salts in the petroleum wastewater. The

Egypt. J. Chem. 56, No. 5,6 (2013) 
conductivity values ranged between $49.95-51.90 \mu \mathrm{s} / \mathrm{cm}$ in summer and 49.80$51.80 \mu \mathrm{s} / \mathrm{cm}$ in winter with average values of 50.92 and $50.75 \mu \mathrm{s} / \mathrm{cm}$, respectively, Low differences were noticed between values taken in the two seasons. Seasonal variation of salinity recorded high value 56.1 for inlet of Suez Oil Company in summer and low value 32.4 in outlet of Electrical Station Company site No. (5), in winter. Table 2 and Fig. 4 indicate that the salinity of the Suez Gulf was increasing from south to north, this accords with Morkos ${ }^{(14)}$ who stated that high salinity of Suez Gulf particularly at its northern part is attributed to the influence of high saline water of the Suez Canal.

TABLE 2. PH, EC and salinity values for the surface seawater samples from Suez Gulf.

\begin{tabular}{|c|c|c|c|c|c|c|c|}
\hline \multicolumn{5}{|c|}{ Season Summer } & \multicolumn{3}{|c|}{ Winter } \\
\hline S.No & Location & $\mathbf{P H}$ & $\begin{array}{c}\text { E.C } \\
\mu \mathrm{s} / \mathrm{cm}\end{array}$ & Salinity & $\mathbf{P H}$ & $\begin{array}{c}\text { E.C } \\
\mu \mathrm{s} / \mathrm{cm}\end{array}$ & Salinity \\
\hline 1 & Suez Harbor. & 7.45 & 51.90 & 33.9 & 7.33 & 51.60 & 33.4 \\
\hline 2 & Al-Nasr Oil Company & 7.38 & 51.59 & 33.9 & 7.58 & 51.80 & 33.6 \\
\hline 3 & Inlet of Suez Oil Company & 8.20 & 49.95 & 56.1 & 8.0 & 49.80 & 51.4 \\
\hline 4 & Outlet of Suez Oil Company. & 8.03 & 50.80 & 54.3 & 8.30 & 50.50 & 51.6 \\
\hline 5 & Outlet of Electrical Station Company. & 7.80 & 50.42 & 32.7 & 7.88 & 50.10 & 32.4 \\
\hline 6 & Fertilizer Factory & 7.50 & 51.60 & 51.8 & 7.42 & 51.50 & 51.5 \\
\hline 7 & Al-Osra beach & 7.23 & 50.70 & 32.9 & 7.35 & 50.60 & 32.8 \\
\hline 8 & Al-Melaha beach & 7.40 & 50.40 & 50.6 & 7.35 & 50.10 & 50.1 \\
\hline \multicolumn{2}{|r|}{ Range } & $\begin{array}{l}7.23- \\
8.20\end{array}$ & $\begin{array}{c}49.95- \\
51.90\end{array}$ & $\begin{array}{l}32.7- \\
56.1\end{array}$ & $\begin{array}{c}7.33 \\
-8.30\end{array}$ & $\begin{array}{l}49.80- \\
51.80\end{array}$ & $\begin{array}{l}32.4- \\
51.6\end{array}$ \\
\hline \multicolumn{2}{|r|}{ Average } & 7.62 & 50.92 & 43.27 & 7.65 & 50.75 & 42.1 \\
\hline
\end{tabular}

E.C: $\mu \mathrm{s} / \mathrm{cm}$

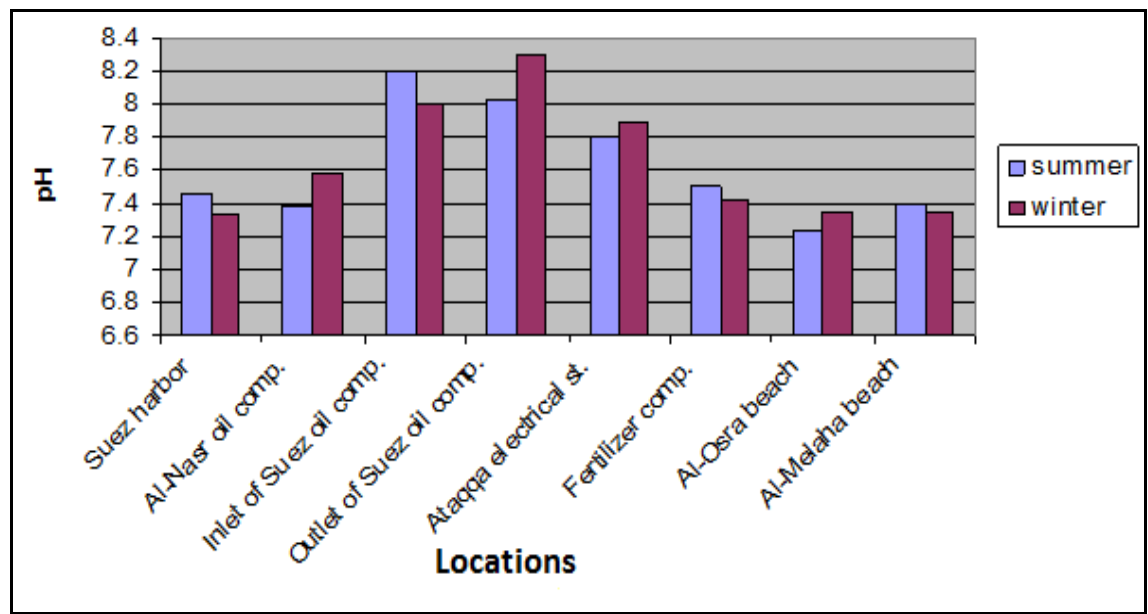

Fig. 2. The seasonal variation of $\mathrm{pH}$ value.

Egypt. J. Chem. 56, No. 5,6 (2013) 


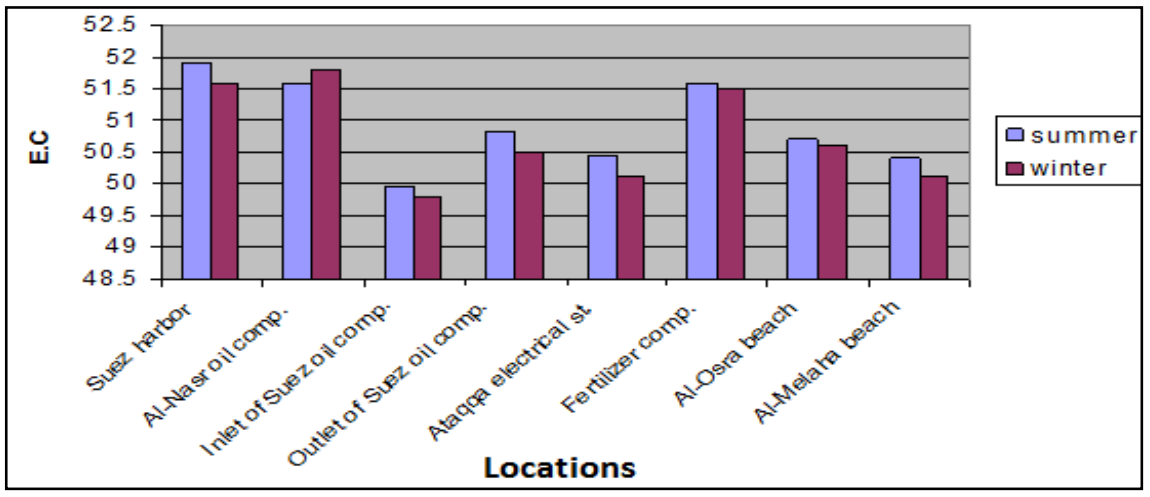

Fig. 3. The seasonal variation of E.C.

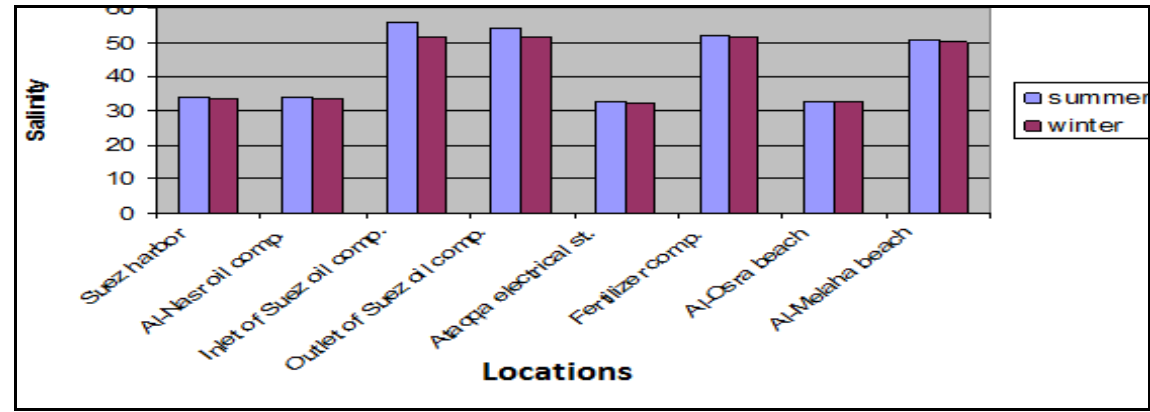

Fig. 4. The seasonal variation of salinity.

Total alkalinity: Alkalinity of water is a measure of its capacity to neutralize acid in other words to absorb hydrogen ions without significant $\mathrm{PH}$ change ${ }^{(15)}$. Values of total alkalinity contents ranged between (80-180) $\mathrm{mg} \mathrm{CaHCO}_{3}$ in summer and (115-200) $\mathrm{mg} \mathrm{CaHCO}_{3}$ in winter with average values 128.12and 156.25 $\mathrm{mg} \mathrm{CaHCO}_{3} / \mathrm{L}$, respectively. This is due to evaporation during summer season .The highest values of alkalinity are in outlet of Suez Oil Company in winter, the lowest values of alkalinity are in Fertilizer Factory in summer (Table 3 and Fig. 5).

TABLE 3. The seasonal variation of total alkalinity.

\begin{tabular}{|c|l|c|c|}
\hline \multicolumn{2}{|c|}{ Season } & Summer & Winter \\
\hline S.No. & \multicolumn{1}{|c|}{ Location } & $\begin{array}{c}\text { Alkalinity } \\
\left.\mathbf{m g ~ C a C O}_{3} / \mathbf{L}\right)\end{array}$ & $\begin{array}{c}\text { Alkalinity } \\
\mathbf{m g ~ C a C O}_{3} / \mathbf{L} \text { ) }\end{array}$ \\
\hline 1 & Suez Harbor. & 110 & 135 \\
\hline 2 & Al-Nasr oil Company & 120 & 145 \\
\hline 3 & Inlet of Suez Oil Company & 140 & 150 \\
\hline 4 & Outlet of Suez Oil Company. & 180 & 200 \\
\hline 5 & Outlet of Electrical Station Company. & 90 & 150 \\
\hline 6 & Fertilizer Factory & 80 & 115 \\
\hline 7 & Al-Osra beach & 145 & 170 \\
\hline 8 & Al-Melaha beach & 160 & 185 \\
\hline \multicolumn{2}{|c|}{ Range } & $80-180$ & $115-200$ \\
\hline \multicolumn{2}{|c|}{ Average } & 128.12 & 156.25 \\
\hline
\end{tabular}

Alkalinity: $\mathrm{mg}(\mathrm{CaCO} / \mathrm{L}) . \quad$ Alkalinity, $\left(\mathrm{mg}\left(\mathrm{CaCO}_{3} / \mathrm{L}\right)\right.$ 


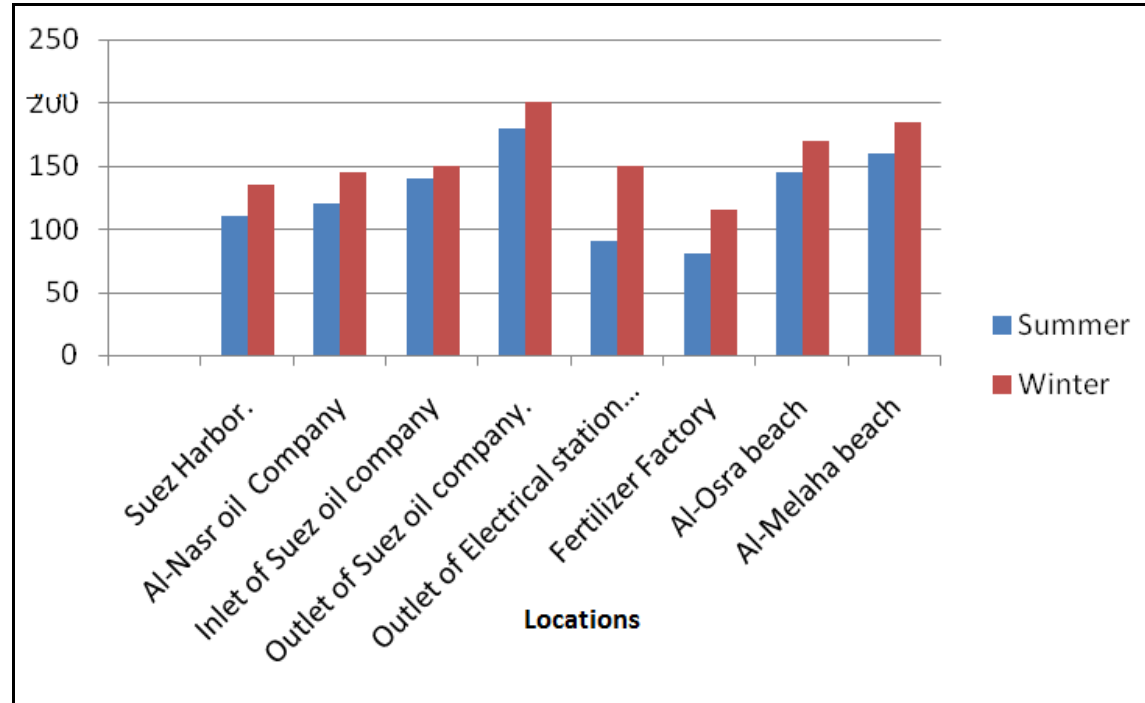

Fig. 5. The seasonal variation of total alkalinity, $\left(\mathrm{mg}\left(\mathrm{CaCO}_{3} / \mathrm{L}\right)\right.$.

Total dissolved solids (TDS), total suspended solid (TSS) and total solids (TS)

Solid suspend: Due to the presence of oil processing companies in studied area which treated the oily- wastewater by flotation process in which solids contents or immiscible liquids that are lighter than water, they will float to the surface in the flotation tank, where they can be skimmed off. The gravity separator units for oil commonly are designed to remove free oil globules larger than $1.5 \mathrm{~mm}{ }^{(16,15)}$.So the outflow wastewater is not free from the oil and suspended solids, Table 4 and Fig. 6 show high values of suspended solids (SS) at the outflow effluent than those of the inflow water and also, the values in winter are higher $46851 \mathrm{mgl}$ than summer $36502 \mathrm{mgl}$. This is due to the presence of the oil globules; such increase in the suspended solids (S.S) is most probably attributed to discharge of huge amounts of suspended solids from the dew-axing and coke distillation department as well as hydrodesulphurization unit directly into the drain. TDS comprise inorganic salts as calcium, magnesium, potassium, sodium, bicarbonates, chlorides and sulphates besides small amount of organic matter that are dissolved in water. The date obtained in Table 4 and Fig. 7 Show the highest values of TDS at Suez Harbor s. No. (1), TDS values ranged between $34965 \mathrm{mglL}$ to $36330 \mathrm{mglL}$ in summer and $34860 \mathrm{mg} \mathrm{L}$, to $36260 \mathrm{mglL}$ in winter with average values $356447.7 \mathrm{mglL}, 35525 \mathrm{mgl}$ respectively .In general TDS values increase than the maximum permissible limit of low $4 \backslash 94$ that TDS $2000 \mathrm{mg} \backslash \mathrm{L}$.

Egypt. J. Chem. 56, No. 5,6 (2013) 
TABLE 4. Seasonal variation of TS, TDS and TSS.

\begin{tabular}{|c|c|c|c|c|c|c|c|}
\hline \multicolumn{2}{|r|}{ Season } & \multicolumn{3}{|c|}{ Summer } & \multicolumn{3}{|c|}{ Winter } \\
\hline S.No. & Location & $\begin{array}{l}\text { T.S } \\
\mathbf{m g l}\end{array}$ & $\begin{array}{l}\text { T.D.S } \\
\text { mgVI }\end{array}$ & $\begin{array}{l}\text { T.S.S } \\
\mathrm{mg} / \mathrm{l}\end{array}$ & $\begin{array}{l}\text { T.S } \\
\text { mgll }\end{array}$ & $\begin{array}{l}\text { T.D.S } \\
\text { mgll }\end{array}$ & $\begin{array}{l}\text { T.S.S } \\
\text { mgll }\end{array}$ \\
\hline 1 & Suez Harbor. & 38904 & 36330 & 11021 & 48058 & 36120 & 12038 \\
\hline 2 & Al-Nasr Oil Company & 38300 & 36113 & 15219 & 48002 & 36260 & 17042 \\
\hline 3 & Inlet of Suez Oil Company & 36432 & 34965 & 1466 & 46542 & 34860 & 16641 \\
\hline 4 & $\begin{array}{l}\text { Outlet of Suez Oil } \\
\text { Company. }\end{array}$ & 38024 & 35566 & 15054 & 44675 & 35350 & 16036 \\
\hline 5 & $\begin{array}{l}\text { Outlet of Electrical } \\
\text { Station Company. }\end{array}$ & 37040 & 35294 & 16640 & 47196 & 35070 & 16726 \\
\hline 6 & Fertilizer Factory & 32709 & 36120 & 17728 & 46102 & 36050 & 20052 \\
\hline 7 & Al-Osra beach & 34890 & 35490 & 11238 & 47830 & 35420 & 12018 \\
\hline 8 & Al-Melaha beach & 35721 & 35280 & 17675 & 46404 & 35070 & 23334 \\
\hline & Range & $\begin{array}{l}32709- \\
38904\end{array}$ & $\begin{array}{l}34965- \\
36330\end{array}$ & $\begin{array}{l}1466- \\
17728 \\
\end{array}$ & $\begin{array}{l}44675- \\
48058 \\
\end{array}$ & $\begin{array}{l}34860- \\
36260\end{array}$ & $\begin{array}{l}12018- \\
23334\end{array}$ \\
\hline & Average & 36502 & 35644 & 13255 & 46851 & 35525 & 35610 \\
\hline
\end{tabular}

T.S, T.D.S \&T.S.S: mglL.

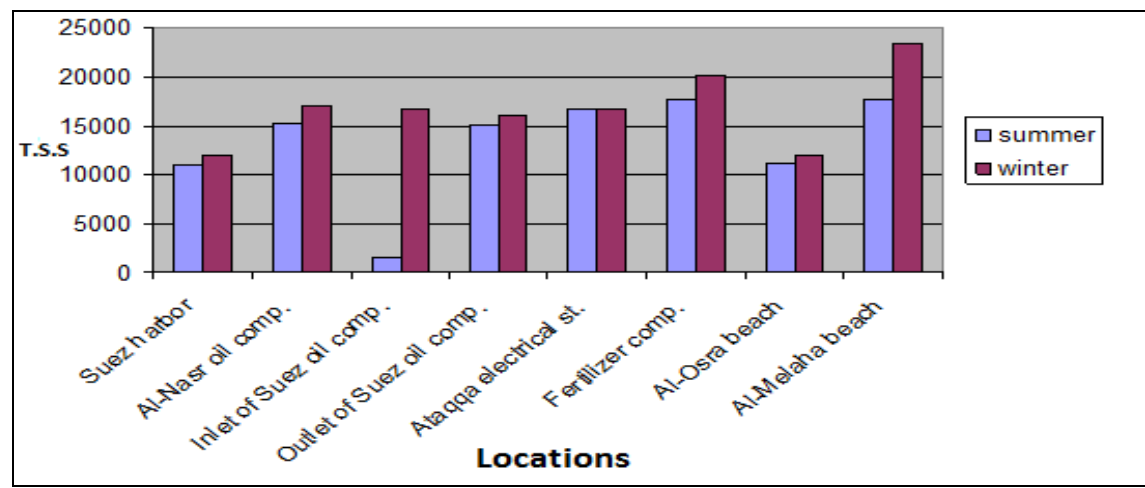

Fig. 6. The seasonal variation of $T$.S.S.

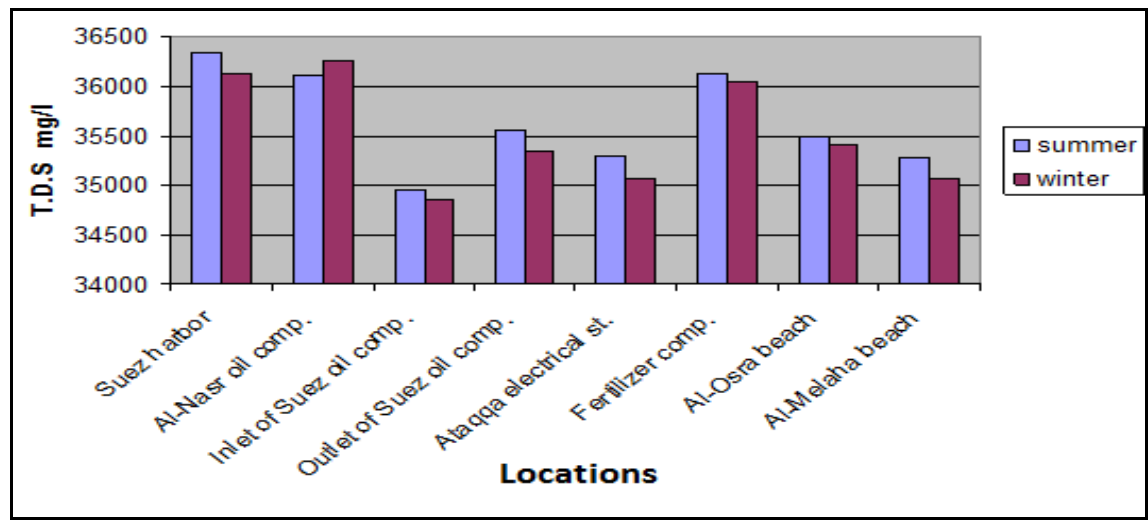

Fig. 7. The seasonal variation of T.D.S.

Egypt. J. Chem. 56, No. 5,6 (2013) 


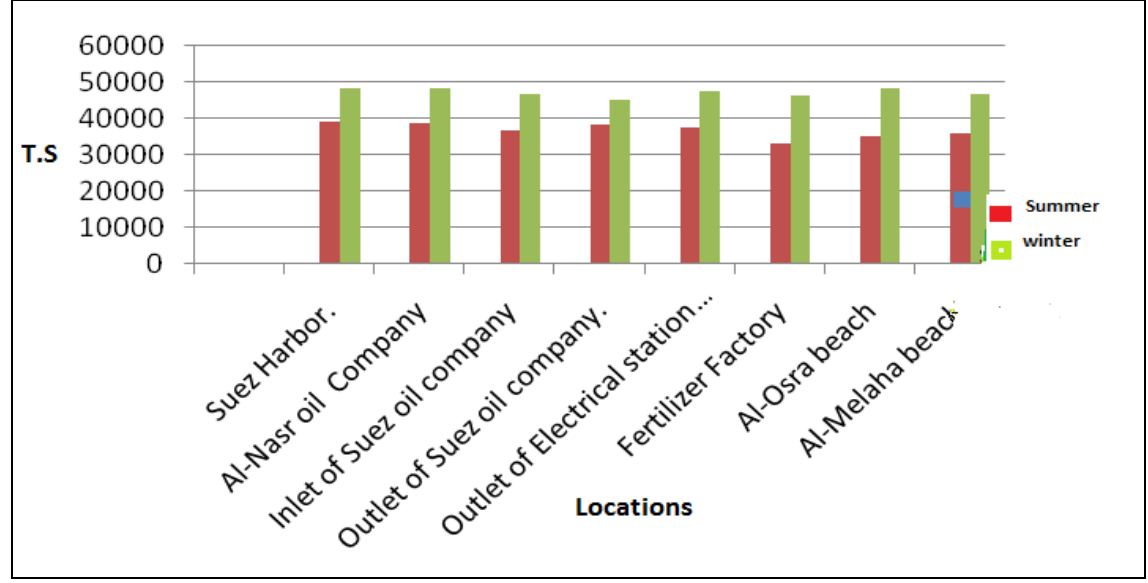

Fig. 8. The seasonal variation of T.S.

The content of dissolved oxygen (DO), chemical oxygen demand (COD) and biochemical oxygen demand (BOD)

The contents of dissolved oxygen ranged from 2.13 to $3.97 \mathrm{mgO}_{2} / \mathrm{L}$ in summer and 1.49-2.24 mgO$/ 2 / \mathrm{L}$ in winter (Table 5 and Fig. 9). This decrease in the content of dissolved oxygen may be due to the presence of mercaptans compounds in the oil participate in consuming the dissolved oxygen, or due to the presence of layer of oil on the surface of the water in the outlet effluent of Gulf prevent the oxygen to be dissolved. While, the content of BOD and COD in the outlet effluent exceeded than that recorded in the inflow water as shown in Table 5 and Fig. $10 \& 11$. Such increase in BOD and COD contents is mainly attributed to the raise in the content of total petroleum hydrocarbons and mercaptans compounds content in the drain, or may reflect the importance of active mixing and gas exchange in this area. Beside, the presence of fertilizer plant in the vicinity and also due to other activities in this area such as fishing farms, sewage stations and agriculture drainage ${ }^{(4,15)}$. Furthermore, the presence of high amount of organic compounds in the effluents enhances the growth of microorganisms in wastewater where the content of BOD in summer ranged between 172-362 $\mathrm{mgO}_{2} / \mathrm{L}$ with average value $250 \mathrm{mgO}_{2} / \mathrm{L}$ also, BOD ranged between 86-212 $\mathrm{mgO}_{2} / \mathrm{L}$ with average value $151 \mathrm{mgO}_{2} / \mathrm{L}$ in winter season. Generally, a BOD of 1 ppm is a characteristic of nearly pure water, as this value reaches 5 ppm it is considered as doubtful pure water ${ }^{(17)}$. Comparing this result of BOD presented in Table 5 with the tolerable level for pure water, higher level was particularly reported at the northern part of the Gulf, indicating the presence of perceptible load of domestic wastes discharging into this region. 
TABLE 5. The content of dissolved oxygen, biochemical oxygen demand and chemical oxygen demand $\left(\mathrm{mgO}_{2} / \mathrm{L}\right)$ of surface water.

\begin{tabular}{|c|l|c|c|c|c|c|c|}
\hline \multicolumn{2}{|c|}{ Season } & \multicolumn{3}{|c|}{ Summer } & \multicolumn{3}{c|}{ Winter } \\
\hline S.No. & \multicolumn{1}{|c|}{ Location } & $\begin{array}{c}\text { DO } \\
\mathbf{m g O}_{2} / \mathbf{l}\end{array}$ & $\begin{array}{c}\text { BOD } \\
\mathbf{m g O}_{2} / \mathbf{l}\end{array}$ & $\begin{array}{c}\text { COD } \\
\mathbf{m g O}_{2} / \mathbf{l}\end{array}$ & $\begin{array}{c}\text { DO } \\
\mathbf{m g O}_{2} / \mathbf{l}\end{array}$ & $\begin{array}{c}\text { BOD } \\
\mathbf{m g O}_{2} / \mathbf{l}\end{array}$ & $\begin{array}{c}\text { COD } \\
\mathbf{m g O}_{2} / \mathbf{l}\end{array}$ \\
\hline 1 & Suez Harbor. & 3.42 & 270 & 36.8 & 2.24 & 140 & 128 \\
\hline 2 & Al-Nasr Oil Company & 2.98 & 232 & 276 & 2.13 & 144 & 296 \\
\hline 3 & $\begin{array}{l}\text { Inlet of Suez Oil } \\
\text { Company }\end{array}$ & 2.46 & 172 & 202.4 & 1.92 & 86 & 264 \\
\hline 4 & $\begin{array}{l}\text { Outlet of Suez Oil } \\
\text { Company. }\end{array}$ & 3.97 & 272 & 231.2 & 2.13 & 146 & 240 \\
\hline 5 & $\begin{array}{l}\text { Outlet of Electrical } \\
\text { Station Company. }\end{array}$ & 2.13 & 362 & 55.2 & 2.02 & 180 & 160 \\
\hline 6 & Fertilizer Factory & 3.55 & 242 & 92 & 1.77 & 212 & 160 \\
\hline 7 & Al-Osra beach & 2.20 & 240 & 66 & 1.49 & 120 & 128 \\
\hline 8 & Al-Melaha beach & 2.23 & 210 & 94 & 1.81 & 180 & 150 \\
\hline & Range & $2.13-$ & $172-$ & $36.8-$ & $1.49-$ & $86-$ & $128-$ \\
& 3.97 & 362 & 276 & 2.24 & 212 & 296 \\
\hline & Average & 2.867 & 250 & 131.7 & 1.938 & 151 & 190.7 \\
\hline
\end{tabular}

BOD \& $\mathrm{COD}\left(\mathrm{mgO}_{2} / 1\right)$.

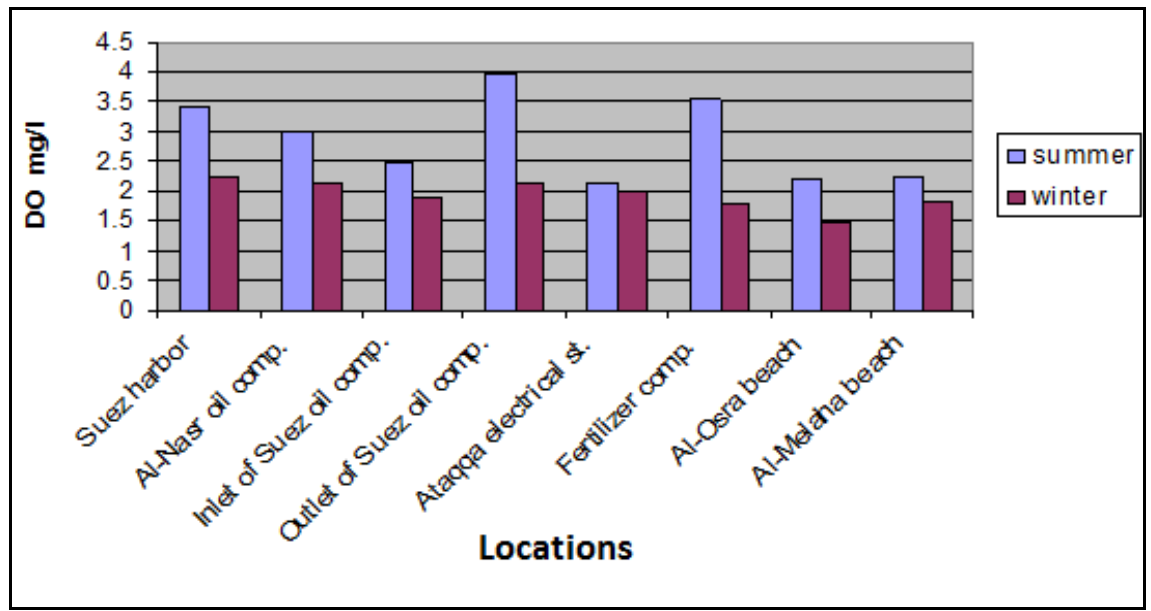

Fig. 9. The content of dissolved oxygen $\left(\mathrm{mg} \mathrm{O}_{2} / \mathrm{L}\right)$. 


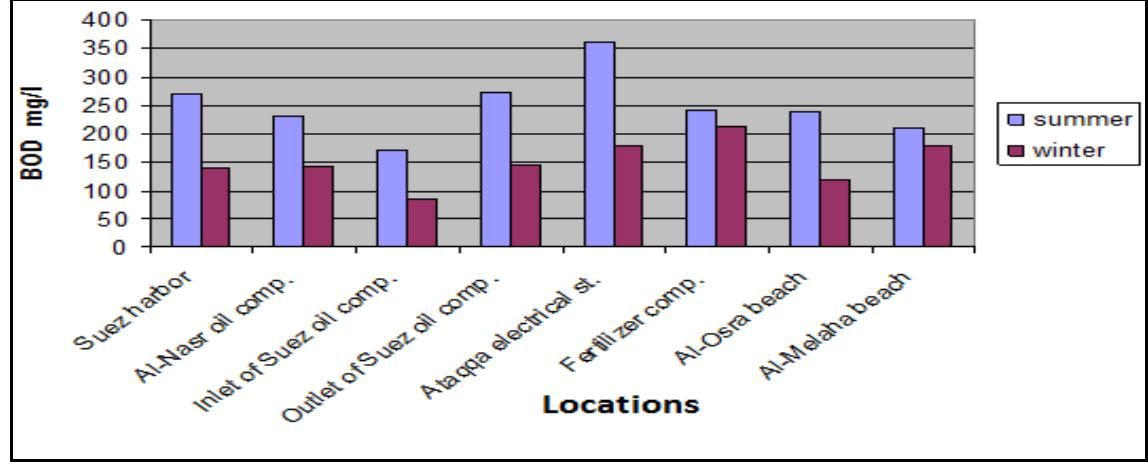

Fig. 10. The content of $\mathrm{BOD}\left(\mathrm{mgO}_{2} / \mathrm{L}\right)$.

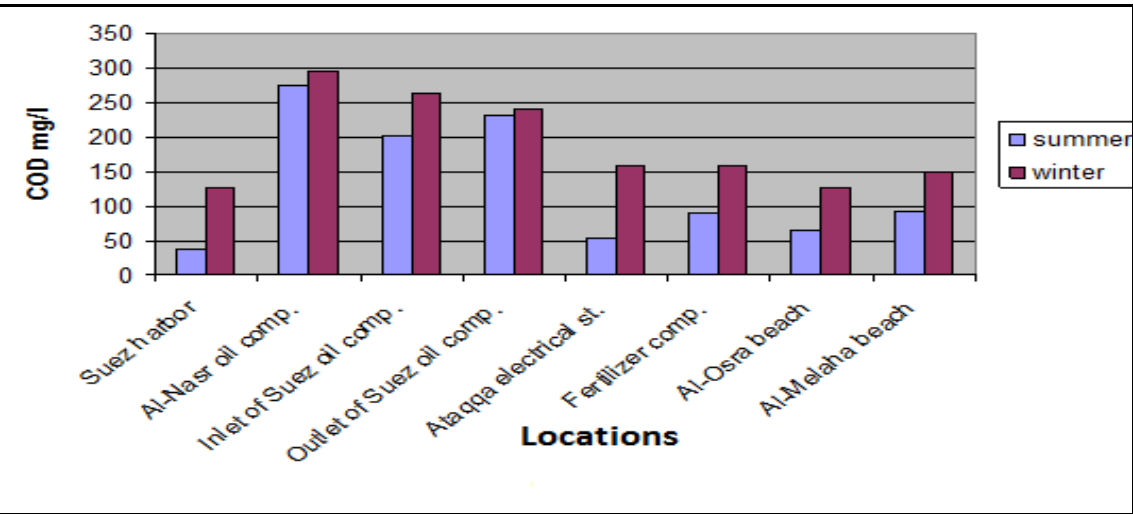

Fig. 11. The content of $\mathrm{COD}\left(\mathrm{mgO}_{2} / \mathrm{L}\right)$.

Determination of nitrite, nitrate, phosphate, sulphate, chloride and fluoride

The nutrient salts are considered essential components for living organisms in natural water. Nitrite is found together with nitrate and ammonia in waste water but its concentration relatively low because of its instability; it is oxidized to nitrate or reduced to ammonia, by both chemical reaction and lor biological by

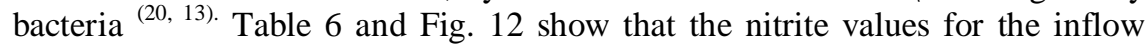
water trend to decrease; this may be due to the reduction of it to ammonia by species of bacteria $^{(19,12)}$, or may be due to the oxidation of it to nitrate also, the presence of petroleum compounds increases the values that confirmed from data recorded in Table 6, Al-Nasr Oil Company and Fertilizer Factory have the highest values $0.188,0.180 \mathrm{ppm}$ for summer and winter seasons, respectively. Nitrate considered the final stage in oxidation of nitrogen compounds and measure quantity of organic matter. Seasonal variation of nitrate recorded in Table 6 and Fig. 13 indicates that nitrate ranged between $0.01 \mathrm{ppm}$ up to $8.02 \mathrm{ppm}$ in summer with average value $2.39 \mathrm{ppm}$, while the concentration in winter ranged between zero $\mathrm{ppm}$ to $7.65 \mathrm{ppm}$ with average value $2.15 \mathrm{ppm}$. As shown from the recorded results, the nitrate content decreased during winter for both inflow and outflow effluent; this may be attributed to its uptake by microorganisms and phytoplankton while the increase during summer may be due to the nitrification of

Egypt. J. Chem. 56, No. 5,6 (2013) 
ammonia to nitrite and nitrate produced by the biochemical decomposition of dead planktons ${ }^{(21)}$, the nitrate values were low in two seasons and within the permissible maximum limits $40 \mathrm{ppm}$ for 4194 . Phosphate concentrations recorded in Table 6 and Fig. 14 show the average value in summer $0.034 \mathrm{mglL}$ and $0.020 \mathrm{mg} \backslash \mathrm{L}$ in winter, the highest concentration of orthophosphate and total phosphate are found to be in summer, this may be attributed to decay of planktons which its body containing phosphate ${ }^{(22)}$. Comparing the present data of nutrients with the previous records in the Suez Gulf and other regions indicates that they are comparable to other records (Table 7). The concentrations of nitrite, nitrate and phosphate were $0.0-0.188,0.01-8.02$ and $15-61 \mathrm{ug} / \mathrm{L}$, respectively at the area of study. Such high concentrations are indicators of the presence of pollutants of high activity viz. sewage discharge, industrial effluents and oil refineries concentrated at the northern part of the Gulf (Suez Bay). Also, it is obvious that the area of investigation can be divided into two regions, Suez Bay region as an eutrophic water (high productivity) and the part of the Gulf as going southward to Safaga, which is considered as oligotrophic water (low productivity). This conforms to Abd EL-Rahman ${ }^{(23)}$ who stated that the Suez Bay is regarded among the eutrophic regions when considering the magnitude of the standing crop of zooplankton. This is particularly true at the in shore stations due to the high load of sewage and industrial wastes discharged into the area. Such pollution can obviously lead to a gradual deterioration of the water quality in the Bay. Accordingly, it is recommended that this wastewater should be treated to improve its quality before being discharged into the Bay. Generally, Thus nitrogen was the limiting factor for phytoplankton growth in the study area ${ }^{(24)}$. The mean concentrations of sulphate, are shown in Table 6 and represented in Fig. 15, respectively, the increase of sulphate values may be due to the petroleum wastes containing sulphure which ranged from 0.1 to $3.4 \%$ (by weight) where sulphure compounds present as sulphate, sulphid and mercaptans. In addition, the reduction of sulphate in petroleum wastes depends on several factors; the most important of these are the concentration of sulphate, organic matter, and both of nutrient and dissolved oxygen necessary to sustain the life of bacteria ${ }^{(22,}$ 4). The data recorded in Table 6 display the highest values 982.79 and 987.02 ppm of sulphate at Inlet of Suez Oil Company site no. (3) For summer and winter, respectively. Chlorides concentrations recorded in Table 6 and Fig. 16 showed that values in summer higher than winter, values in summer ranged between $100.57-559.63 \mathrm{mg} \backslash \mathrm{L}$ with average values $300.68 \mathrm{mg} \backslash \mathrm{L}$. while in winter values ranged between $98.68-386.79 \mathrm{mg} \backslash \mathrm{L}$ with average $309.03 \mathrm{mg} \backslash \mathrm{L}$. Flouride are present as fluorspar in rocks (limestone, sandstone) and as cryolite in igneous rocks (granite) ${ }^{(25)}$. The seasonal variation of fluoride concentration is recorded in Table 6 and graphically represented in Fig. 17 for samples .The highest values $1.13,1.11 \mathrm{ppm}$ are for Inlet of Suez Oil Company site no. (3) in summer and winter seasons, respectively due, to decay of living organism, and the presence of the crust earth, rocks, ground water containing fluoride during the drilling. 
M.M. Emara et al.

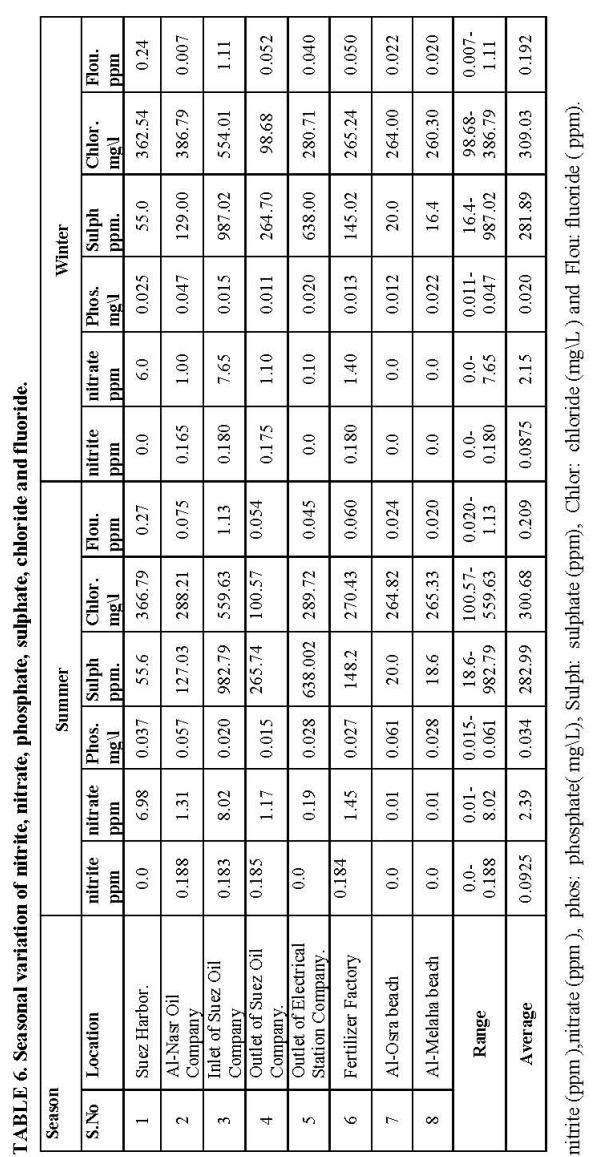




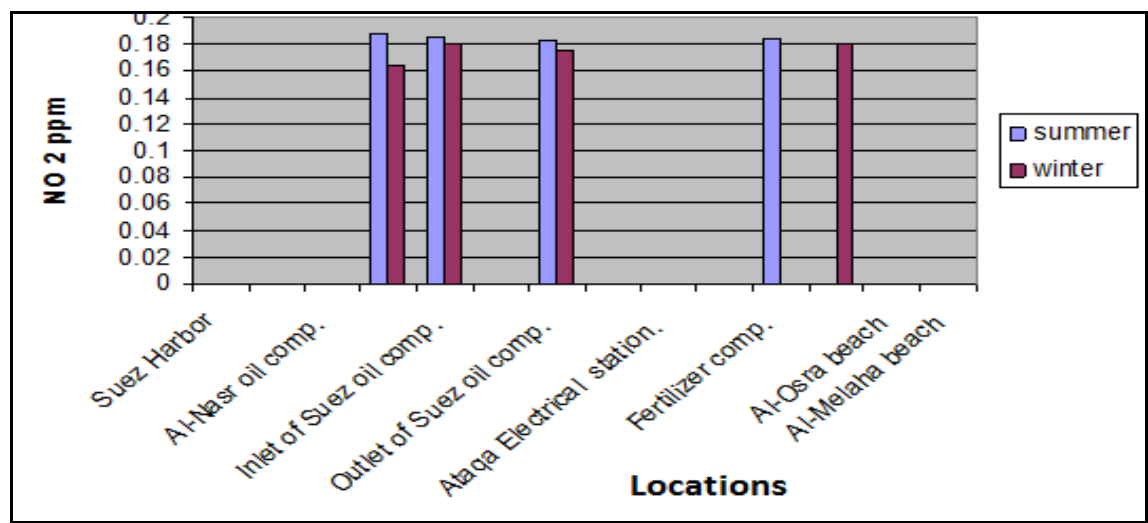

Fig. 12. The seasonal variation of nitrite content $\left(\mathrm{NO}_{2}^{-}\right) \mathrm{ppm}$.

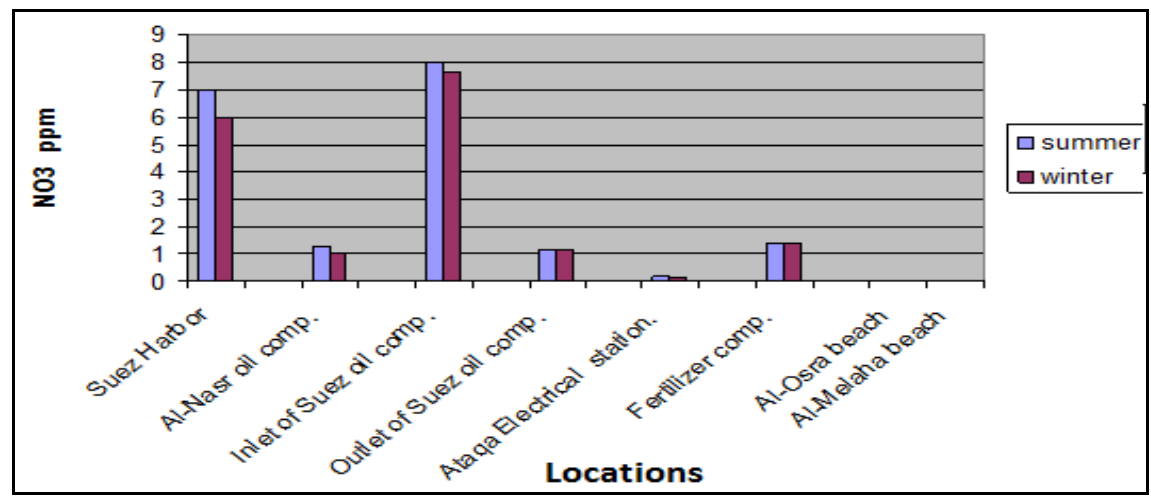

Fig. 13. The seasonal variation of nitrate $\left(\mathrm{NO}_{3}\right) \mathrm{ppm}$.

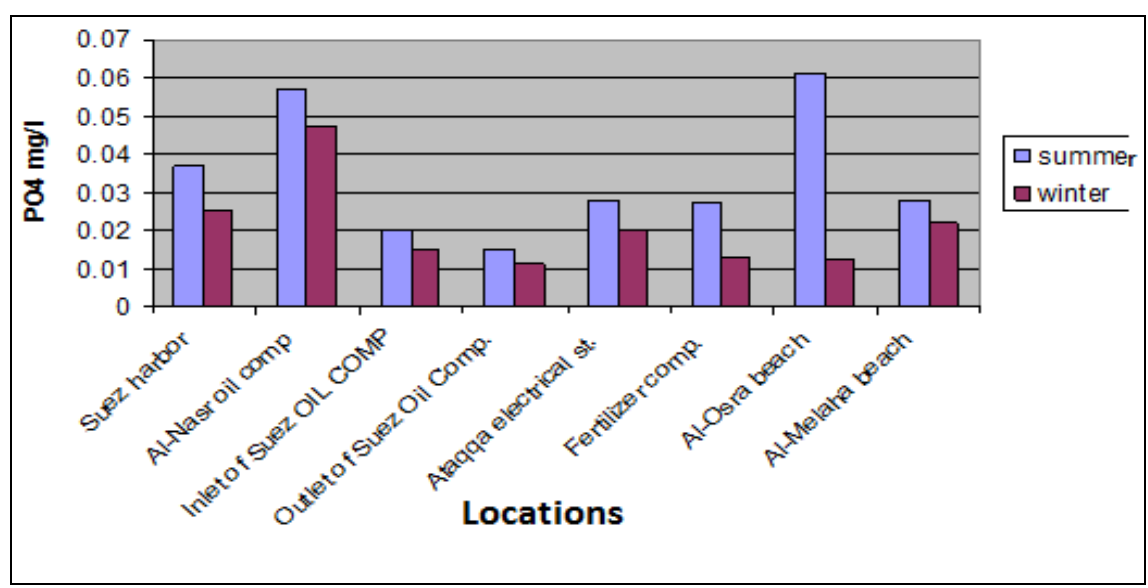

Fig. 14. The concentration of phosphate $\left(\mathrm{PO}_{4}\right) \mathrm{mg} / \mathrm{L}$.

Egypt. J. Chem. 56, No. 5,6 (2013) 
TABLE 7. Nutrient salts concentrations (ug/L) of seawater in the present study compared with other region.

\begin{tabular}{|c|c|c|c|c|c|}
\hline Area & $\mathrm{NH}_{3}-\mathrm{N}$ & $\mathrm{NO}_{2}-\mathrm{N}$ & $\mathrm{NO}_{3}-\mathrm{N}$ & $\mathrm{PO}_{4}-\mathrm{P}$ & References \\
\hline Gulf of Suez & $\begin{array}{l}0.18- \\
4.14\end{array}$ & $\begin{array}{l}0.07- \\
0.45\end{array}$ & $\begin{array}{l}0.48- \\
4.6\end{array}$ & $0.8-1.04$ & (3) \\
\hline AL Khor, Suez & 3.54 & 0.38 & 2.06 & 0.62 & (26) \\
\hline Gulf of Suez & 1.54 & 0.20 & 0.52 & 0.47 & $(27)$ \\
\hline Suez Canal & 2.44 & 0.59 & 2.03 & 0.81 & (27) \\
\hline Suez Bay & 3.25 & 0.49 & 1.48 & 0.85 & (28) \\
\hline Suez Bay & 8.86 & 0.33 & 3.42 & 0.45 & (29) \\
\hline Jeddah & $\begin{array}{ll}---- \\
-\end{array}$ & 0.28 & 9.69 & $\begin{array}{ll}---- \\
\end{array}$ & (3) \\
\hline Dongonab Bay & ----- & ----- & $4.9-7.2$ & $0.3-1.5$ & (30) \\
\hline Abu Qir Bay & 1.23 & 0.07 & 0.88 & 0.58 & (31) \\
\hline $\begin{array}{l}\text { Eastern harbor of } \\
\text { Alexandria }\end{array}$ & 3.16 & 0.95 & 6.79 & 0.56 & (32) \\
\hline EL Max Bay & 20.38 & 0.48 & 1.87 & 1.62 & (33) \\
\hline Suez Gulf & ------- & ------ & 0.17 & ------ & (4) \\
\hline Suez Gulf & ------ & $0.0-0.188$ & $0.01-8.02$ & $15-61$ & This work \\
\hline $\begin{array}{l}\text { Oligotrophic level } \\
\text { Eutrophic level }\end{array}$ & $\begin{array}{c}0.5 \\
2.02 \\
\end{array}$ & $\begin{array}{l}---- \\
---- \\
\end{array}$ & $\begin{array}{l}0.5 \\
4.0 \\
\end{array}$ & $\begin{array}{c}0.05 \\
--- \\
\end{array}$ & $(34,35)$ \\
\hline
\end{tabular}

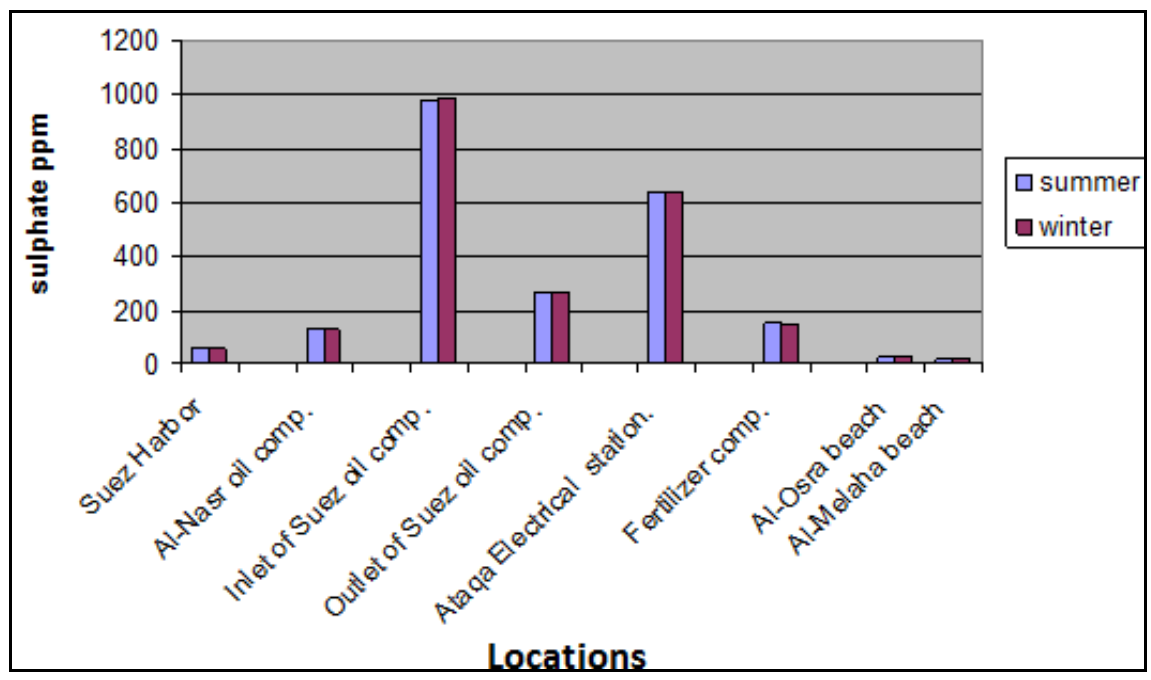

Fig. 15. The seasonal variation of sulphate (ppm). 


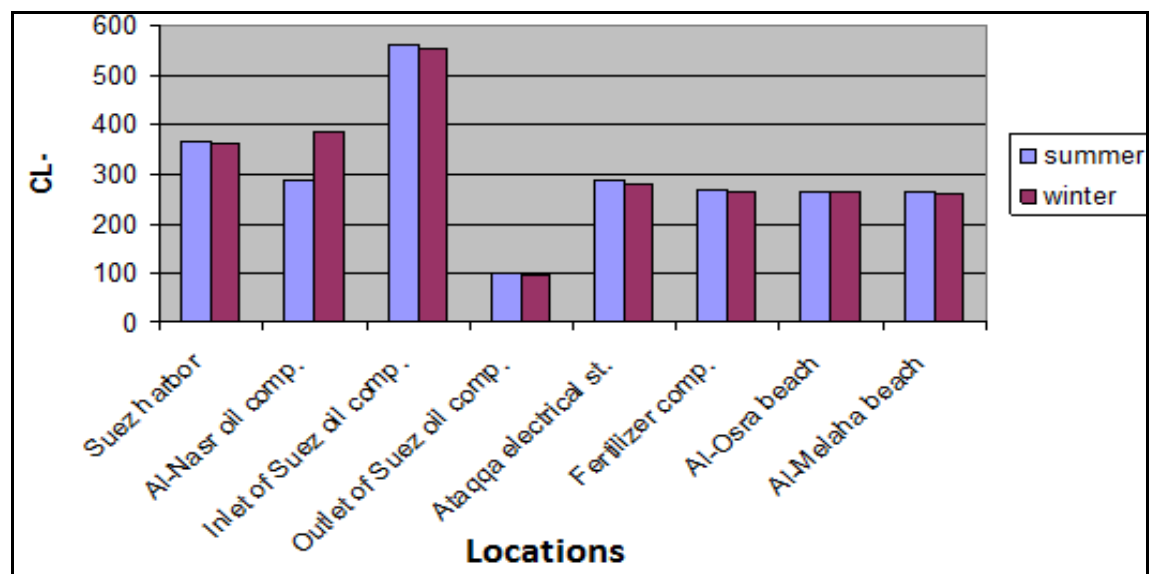

Fig. 16. The seasonal variation of $\mathrm{Cl}^{-} \mathrm{mg} / \mathrm{L}$.

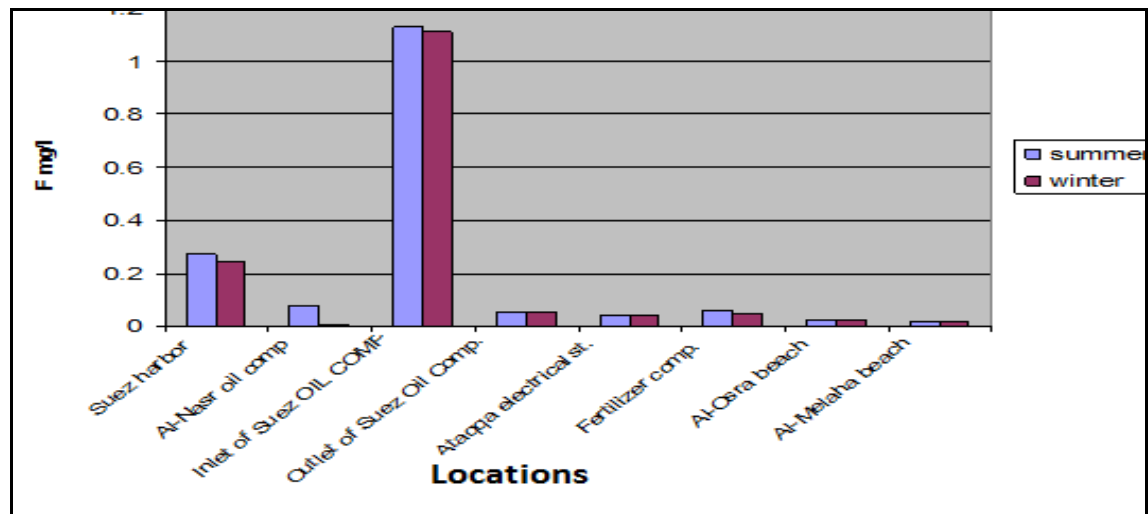

Fig. 17. The seasonal variation of $\left(F^{-}\right) \mathrm{ppm}$.

\section{Conclusion and Recommendations}

The discussion revealed general physico-chemical properties of seawater such as PH values, alkalinity, T.S.S, conductivity, nitrates, phosphates, sulphates, chlorides, salinity, T.D.S, BOD and COD:

1. water samples were analyzed for $\mathrm{PH}$ values, alkalinity, salinity and electronic conductivity which indicated that $\mathrm{PH}$ values are slightly alkaline varing from region to another depending upon the location of sampling and independent on the season, alkalinity are higher in winter than summer this is due to evaporation during summer season, Conductivity value of seawater samples don't differ in all locations except conductivity in certain locations such as Suez Harbor and Al-Nasr Oil Company; this may be related to mixing of salty water from the Suez Gulf with oil during the process of withdrawing petroleum considered as a source of salts in the petroleum wastewater.

2. Results of BOD varied between 36.8 up to $213 \mathrm{mg} \mathrm{O} 2 / \mathrm{L}$ in summer and 86 up to $212 \mathrm{mg} \mathrm{O} / \mathrm{L}$ in winter. BOD are higher in some samples due to activities 
in these areas ${ }^{(36)}$, also COD varied from $36.8-276 \mathrm{mg} \mathrm{O} / \mathrm{L}$ in summer and 128$296 \mathrm{mg} \mathrm{O} / \mathrm{L}$ in winter, the highest values of COD are observed in site no.(2). Such increase in BOD and COD contents is mainly attributed to the raise in the content of total petroleum hydrocarbons and mercaptans compounds content in the drain beside, the presence of fertilizer plant in the vicinity and also due to other activities in this area such as fishing farms, sewage stations and agriculture drainage.

3. The distribution of some anions in seawater was studied, the higher values of anions are chlorides followed by sulphate, phosphate and the lowest one is nitrite and it was the limiting factor for phytoplankton growth in the Suez Gulf.

4. The Suez Bay area is regarded among the eutrophic region and highly polluted due to its relation with sewage and/or industrial activities which distributed along the western coast of the Bay.

5. The concentration is relatively higher than recommended in the regulations of the Egyptian low of environment of No.4/1994. Results obtained from the present study should be considered when implementing a strategy for the protection and management the Suez Gulf, Needless to say that such kind of pollution will obviously lead to a gradual deterioration of the water quality of the Bay.

6. More detailed studies are required to assess the impact of hydrodevelopment projects and evaluate its effect on the studied area and monitoring should be conducted at least twice per year.

7. Because of the Suez Gulf is used in many areas as a recipient for wastewater from different sources, this study recommended that pollution control for wastewater disposing into it should be improved.

8. Serious commitment should be applied for the environmental law for 1994 to protect water and beaches.

Acknowledgments: The authors gratefully thank the Chemistry Department, Faculty of Science (Boys) Al-Azhar University and Egyptian Petroleum Research Institute, Nasr city, Cairo, Egypt for helping to carry out the field work.

\section{References}

1. Pekey. H., Karakas, D., Ayberk, S ., Tolun, L. and Bakoglu, M., Ecological risk assessment using trace elements from surface sediments of Izmit bay (Northeastern Marmara Sea) Turkey. Marine Pollution Bulletin, 48, 964-953 (2004).

2. Samanidou V.F. and Papadoyanis I.N.J., Environ. Sci. Health, A27 (3), 587-601 (1992) .

3. Mohamed A. Hamed and Tarek, O.S., Effect of pollution on the water quality of the Gulf of Suez. Egypt J. Aquat BioL < S Fish., 4 (d), 161-178 (2000)

4. Mohamed I., Omayma A., Nazik.A F., Rabie S. and Moustafa M., Assessment of surface water quality of Suez Gulf. Al-Azhar Bull.Sci. 23 (1), 47-58 (June) (2012).

Egypt. J. Chem. 56, No. 5,6 (2013) 
5. Shahine, Eman A.A, Environmental pollution assessments for some human activities in light of chemical studies of water pollution, M.Sc. Thesis, Faculty of Science, (Girls), Al-Azhar University (2005) .

6. Van Vooren, L., Van De Steene, M., Ottoy, J-P. and Vanrolleghem, PA., Water Science, $\mathbf{4 3} \& 7$ (2003).

7. REMIP WORKING GROUP 2 Remip, JICA and EEAA, State oil pollution and management in Suez Gulf region, page 15 (2008).

8. LAEA-TECDOC-Collection and preparation of bottom sediment samples for analysis of radionuclide and trace elements International Atomic Energy Agency ( 2003b)

9. Annual Book of ASTM Standards Vols. 11.01 and 11.02, Am. Soc. Test Mater., Philadelphia (1992).

10. Standerd Methods for the Examination of Water and Wastewater $20^{\text {th }} \mathrm{ed}$ American Public Health. Association (APHA), American Work Water Association (AWWA), and Water Environment Federation 9WEF), Edited by Clescrei L.S., Greenberg A.E. and Eaton A.D (1998) .

11. Patnaik. Hand Book of Environmental Analysis, Lewis Publishers (1997).

12. Capurro L.R. "Oceanography for Practicing Engineers". Barnea and Noble Inc., NewYork (1970).

13. Barakat M.A.K., EL-Sayed and Ouf, E.A., Evaluation of drinking water quality in delta of Egypt. Egyptian Petroleum Research institutes (EPRI) Cairo, Egypt. (Accepted) October 22. Egypt. J. Petrol. 18 (1), 81-92 (2009).

14. Morcos S.A. The tidal currents in the southern part of Suez Canal. Gen. Ass. of Helsinki, Finland, 51, 307-312 (1970).

15. Omayma,A. Mousa, Nazik.A Farid, Rabie Saad and Moustafa M. Emara,.Assessment of surface water quality of Suez Gulf. Mohamed Ibrahim ${ }^{(a)}$ Al-Azhar Bull.Sci. 23 (1), 47-58 (June) (2012).

16. Paul L. Bishop, Pollution Prevention, Fundamental and Practice, Th Mc Graw-Hill Companies (2000).

17. Anon "Environmental Central and Public Health, Water Analysis, Standards and Treatment, Eyre and Spottiswoode Ltd, ECPH, 131 (1975).

18. World Health Organization (WHO). Nitrate and N- nitro compounds, Geneva, Environmental Health Criteria 5 (1975).

19. Omayma E. Ahmed, Mageed M. Soliman, Nazik A. Farid and Abd EL- Rahman Mousa, Assessment of water quality of Alexandria sea water coast. (Accepted) Al-Azhar International Scientific Conference Environment, Development, and Nanotechn. 2010. ology (ISCAZ 2010) March 22-24 (2010) . 
20. Cecen. F. and Orak, E., Nitrification of fertilizer wastewaters in a biofilm reactor. Journal of Chemical Technology and Biotechnology, 65 (3), 229-238 (1996).

21. El-Sabah, M.I. and Beltagy, A.I., Bull. Institute, Oceanography. \& Fish. 9, 78-82 (1982) .

22. Fathy, K.A., Ph.D. Thesis, Faculty of Science, University of Suez Canal (2002).

23. Abd EL-Rahman N.S., Ecological studies on the distribution of zooplankton communities in the northern part of the Suez Gulf 'Suez Bay. M. Sc. Thesis, Faculty of Science, Suez Canal University, 316 pp (1993)

24. Redfield A.C., Katchum B. H. and Richard S. A., The Influence of Organism on The Composition of Seawater in the Sea, John Wiley and Sons, New York, Vol. 2, p26-77 (1963).

25. Charless R. Cox., Operation and Control of Water Treatment Processes, World Health Organization, Monograph series No.49, Geneva (1969)

26. Hamed M.A., Environmental studies on AL Khor area, Suez, Egypt. J. Environmental Science. Faculty of Science, Mansoura University. 75,181-201pp (1998) .

27. Hamed M.A., Determination of some microelements in the aquatic system and their relation to the efficiency of marine life. Ph. D. Thesis. Faculty of Science, Mansoura University, $120 \mathrm{pp}$ (1996) .

28. Hamed M.A., Sea water quality at the northern part of the Gulf of Suez and the nearby area of the Suez Canal. M. Sc. Thesis. Faculty of Science, Mansoura University, 81pp (1992) .

29. Mohamed, A.A., Study of iodine cycle in Suez Bay. M. Sc. Thesis, Faculty of Science, Helwan University, Egypt, 90 pp (1994) .

30. Farah O.M., Symposium of Marine Chemistry in the Arab Region. Suez, Egypt. April, 21-23 (1991) .

31. Fahmy, M. A., Hydrochemistry and nutrients of Abu-Qir Bay during summer, 1995. Bull. Fac. Sci., Alex. Univ. 37 (2),171-186 (1997) .

32. Aboul-Kissum, T.A., Cycles of carbon, nitrogen and phosphorus in the marine environment in Alexandria region. M, Sc. Thesis, Fac. Sci., Alex. University (1987).

33. Tayel, F. F., Fahmy, M.A. and Shenadah, M.A., Studies on physicochemical characteristics of the EL Mex Bay and new Dekhaila Harbour waters of Alexandria. Bull. Nat. Inst. Ocean. \& Fisheries, ARE, 22,1-18 (1997).

34. Skrivanic, V. and Strin, J., Basic Physical, Chemical and Biological Data Reports. R.V. "A Mohorov ICIC" Adriatic cruises, 1974-76. Hydrographic Inst \& Yugoslav Navy-split, 175 pp (1982).

35. Franco, P., Fattori influent sulla productivity prim aria dell Adriatic $\odot$ settentrionala. Proc. Int. Conf., Problems of the Adriatic Sea Trieste, pp. 155-174 (1983).

Egypt. J. Chem. 56, No. 5,6 (2013) 
36. Louis, M.A., Environmental Science and Technology .VI (10), p. 901 October (1974).

\section{دراسة فيزوكيميائيه على مياه البحر السطية في منطقة شمال غرب خليج السويس فميسانه

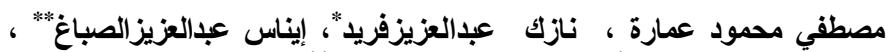

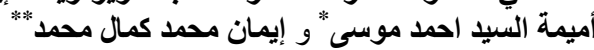

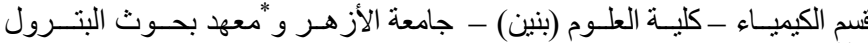

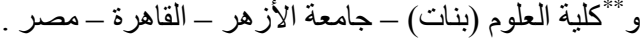

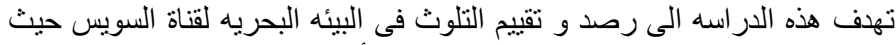

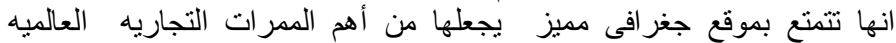

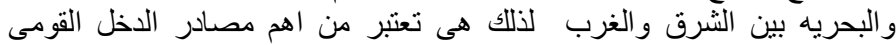

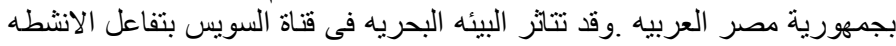

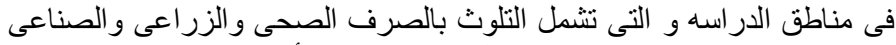

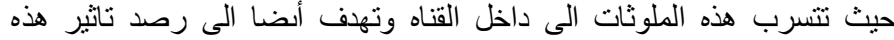

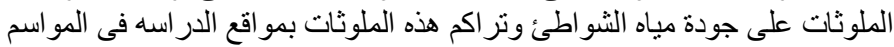

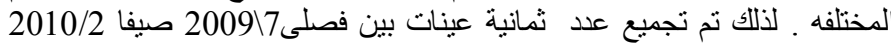

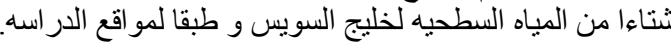

التركيزات أعلى نسبيا من الموصى بها في لوائح قانون البيئة المصرية لسنة

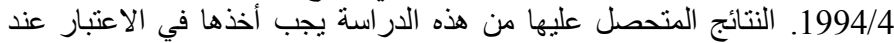

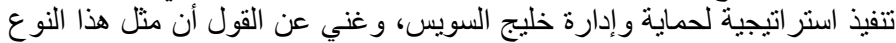

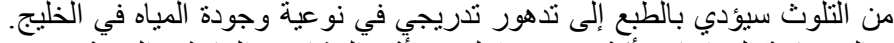

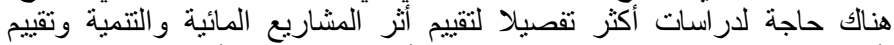

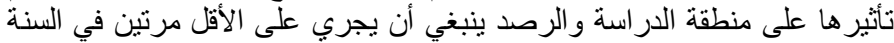

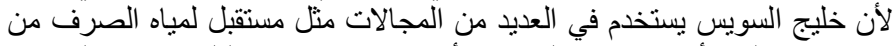

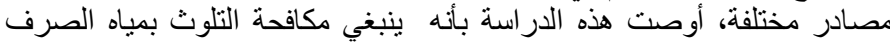

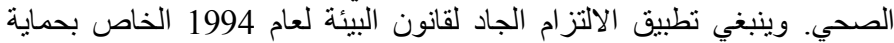

المياه و الثو اطئ. 